University of Nebraska - Lincoln

DigitalCommons@University of Nebraska - Lincoln

DIFFERENCES AMONG MYCORRHIZAL FUNGI FOR MINERAL UPTAKE PER ROOT LENGTH OF SWITCHGRASS GROWN IN ACIDIC SOIL

R. B. Clark

rbclark2690@mail.burgoyne.com

Follow this and additional works at: https://digitalcommons.unl.edu/usdaarsfacpub

Part of the Agricultural Science Commons

Clark, R. B., "DIFFERENCES AMONG MYCORRHIZAL FUNGI FOR MINERAL UPTAKE PER ROOT LENGTH OF SWITCHGRASS GROWN IN ACIDIC SOIL" (2002). Publications from USDA-ARS / UNL Faculty. 524. https://digitalcommons.unl.edu/usdaarsfacpub/524

This Article is brought to you for free and open access by the U.S. Department of Agriculture: Agricultural Research Service, Lincoln, Nebraska at DigitalCommons@University of Nebraska - Lincoln. It has been accepted for inclusion in Publications from USDA-ARS / UNL Faculty by an authorized administrator of DigitalCommons@University of Nebraska - Lincoln. 


\title{
DIFFERENCES AMONG MYCORRHIZAL FUNGI FOR MINERAL UPTAKE PER ROOT LENGTH OF SWITCHGRASS GROWN IN ACIDIC SOIL
}

\author{
R. B. Clark* \\ 2690 Aquarius Circle, St. George, UT 84790
}

\begin{abstract}
Plants commonly encounter deficient and/or toxic levels of mineral elements when grown in acidic soil, and arbuscular mycorrhizal fungi (AMF) have potential to overcome many of these effects. Switchgrass (Panicum virgatum L.) was grown in acidic Lily soil (Typic Hapludult) at $\mathrm{pH}_{\mathrm{Ca}} 4$ and 5 (soil : $10 \mathrm{mM}$ $\left.\mathrm{CaCl}_{2}, 1: 1\right)$ and inoculated with Glomus $(G$.) clarum, G. diaphanum, G. etunicatum, G. intraradices, Gigaspora (Gi.) albida, Gi. margarita, Gi. rosea, and Acaulospora (A.) morrowiae to determine differences among mycorrhizal (AM) plants for mineral uptake per root length (RL). Shoots of AM plants grown in $\mathrm{pH}_{\mathrm{Ca}} 4$ and 5 soil had extensive mineral nutrient content (per plant) differences, and $\mathrm{AM}$ plants grown in $\mathrm{pH}_{\mathrm{Ca}} 4$ soil generally had higher and wider ranges of mineral contents than plants grown in $\mathrm{pH}_{\mathrm{Ca}} 5$ soil. Mineral uptake per $\mathrm{RL}$ varied
\end{abstract}

\footnotetext{
*Formerly Plant Physiologist, Appalachian Farming Systems Research Center, USDAARS, 1224 Airport Rd., Beaver, WV 25813. E-mail: rbclark2690@mail.burgoyne.com
} 
extensively among AM plants. The AM plants generally enhanced uptake of phosphorus $(\mathrm{P})$, nitrogen $(\mathrm{N})$, sulfur $(\mathrm{S})$, potassium $(\mathrm{K})$, calcium $(\mathrm{Ca})$, magnesium $(\mathrm{Mg})$, zinc $(\mathrm{Zn})$, and copper $(\mathrm{Cu})$ and reduced uptake of manganese $(\mathrm{Mn})$, iron $(\mathrm{Fe})$, boron (B), and aluminum (Al). The G. etunicatum plants particularly had higher $\mathrm{P}, \mathrm{N}, \mathrm{S}, \mathrm{K}, \mathrm{Mg}, \mathrm{Zn}$, and $\mathrm{Cu}$ uptake compared to the other AM plants. Most AMF isolates used were effective in enhancing mineral uptake and reducing excess amounts of toxic elements in shoots.

\section{INTRODUCTION}

Plants commonly encounter deficient and/or toxic levels of mineral elements when grown in acidic $(\mathrm{pH}<\sim 5)$ soil. ${ }^{[1,2]}$ Arbuscular mycorrhizal fungi (AMF) have potential to help overcome many detrimental effects in acidic soil and provide plant tolerance to these conditions. ${ }^{[2-7]}$ One beneficial effect of AMF for alleviating mineral stresses in acidic soil has been attributed to the ability of AMF hyphae to extend beyond the usual nutrient absorption zone of roots and transport essential nutrients to the host plant that roots per se would not otherwise contact, especially $\mathrm{P}^{[2]}$ Improved tolerance of plants to acidic soil may also be attributed to restricted acquisition of and/or exposure to toxic elements, especially $\mathrm{Al}$ and $\mathrm{Mn} .^{[6,8-20]}$

Plant species and genotypes within species exhibit large differences for tolerance to acidic soils, ${ }^{[21-24]}$ and so do AMF species and isolates differ in providing plant tolerance to acidic soil. ${ }^{[6,9,11,15,16,25-28]}$ Much of this has been attributed to AMF enhancement of essential mineral nutrient acquisition and providing plant protection against toxic elements. ${ }^{[2]}$ Nevertheless, effectiveness of AMF colonized roots for acquiring mineral elements has received only limited attention. For example, the dominant mycorrhizal contribution to maize (Zea mays L.) and soybean [Glycine max (L.) Merr.] grown in two tropical soils, regardless of soil $\mathrm{pH}$, was associated with enhanced $\mathrm{P}$ uptake per $\mathrm{RL}\left(\mathrm{P}_{\mathrm{RL}}\right)$. $^{[17]}$ The $\mathrm{P}_{\mathrm{RL}}$ uptake values were generally 2-3-fold higher for mycorrhizal (AM) compared to nonmycorrhizal (nonAM) plants. ${ }^{[29]}$ Differences were also noted among AMF species. ${ }^{[30]}$ For example, Acaulospora (A.) laevis subterraneum clover (Trifolium subterraneum L.) had 2.5-3.0-fold higher $\mathrm{P}_{\mathrm{RL}}$ uptake values compared to Glomus sp and Scutellospora (S.) calospora plants.

The objective of this study was to determine differences among eight AMF isolates for mineral uptake per RL of switchgrass (Panicum virgatum L.) grown in acidic soil. 


\section{MATERIALS AND METHODS}

The AMF isolates used in this study are listed in Table 1. Seven of the isolates were obtained from the INVAM Program (International Collection of Arbuscular and Vesicular-Arbuscular Mycorrhizal Fungi, West Virginia University, Morgantown) and one isolate (Gi. margarita) was obtained from D. D. Douds (USDA-ARS, Philadelphia, PA). Considerable description and conditions for isolation of the AMF isolates are provided in Morton et al. ${ }^{[31]}$

Acidic Lily soil (fine loamy, siliceous, mesic, Typic Hapludult) collected from south central West Virginia was used to grow plants. Some properties of the soil before steam treatment were $43 \%$ sand, $39 \%$ silt, $18 \%$ clay; $4.7 \%$ organic matter (Walkley-Black procedure); $3.89 \mathrm{pH}_{\mathrm{Ca}}$ (soil : $10 \mathrm{mM} \mathrm{CaCl}_{2}, 1: 1$ ) and 4.48 $\mathrm{pH}_{\mathrm{W}}$ (soil : water, $1: 1$ ); $0.06 \mathrm{dS} \mathrm{m}^{-1}$ electrical conductivity (soil : water, $1: 1$ ); 3.09 P (Bray-I extractable), 70.0 S, 69.5 K, 45.8 Ca, 5.06 Mg, 2.30 Na (1 $\mathrm{M} \mathrm{NH}_{4}$ acetate extractable), $302 \mathrm{Al}(1 \mathrm{M} \mathrm{KCl}$ extractable), $33.1 \mathrm{Mn}, 53.8 \mathrm{Fe}, 0.716 \mathrm{Zn}$, $0.125 \mathrm{Cu}(5 \mathrm{mM}$ DTPA extractable), $0.93 \mathrm{~B}$ (hot water extractable) in $\mathrm{mg} \mathrm{kg}{ }^{-1}$ soil; $3.82 \mathrm{cmol}_{\mathrm{c}} \mathrm{kg}^{-1}$ soil cation exchange capacity; and $88 \% \mathrm{Al}$ saturation. Methods of analyses for the various elements/ properties are described in Page et al. ${ }^{[32]}$

Air-dried soil was sieved to pass a $2-\mathrm{mm}$ screen, steam treated at $100^{\circ} \mathrm{C}$ for $30 \mathrm{~min}$, allowed to cool at ambient temperature overnight, again steam treated at $100^{\circ} \mathrm{C}$ for $20 \mathrm{~min}$, and allowed to stand seven days before being fertilized with $\mathrm{NH}_{4} \mathrm{NO}_{3}$ at $143 \mathrm{mg} \mathrm{kg}^{\mathrm{n} 1}$ soil. One batch of soil was not amended to provide soil near $\mathrm{pH}_{\mathrm{Ca}}$ 4, while a second batch had $\mathrm{pH}_{\mathrm{Ca}}$ increased to 5 with $2.5 \mathrm{~g}$ $\mathrm{CaCO}_{3} \mathrm{~kg}^{-1}$ soil. The amount of $\mathrm{CaCO}_{3}$ added was limited so that conditions for amended soil still remained fairly acidic.

Inoculum of each AMF isolate was multiplied in the laboratory using sudangrass [Sorghum bicolor (L.) Moench] as the host plant grown in Lily soil : sand $(1: 1)$ mixtures $\left(\mathrm{pH}_{\mathrm{Ca}}=5.5\right)$. Inoculum of each $\mathrm{AMF}$ isolate consisted of soil : sand mix containing root fragments + hyphae + spores. Similar potential of each AMF isolate was added to soil. Because Gigaspora AMF did not readily form spores during inoculum multiplication yet readily colonized roots (R. B. Clark and S. K. Zeto, personal observations), inoculum of each AMF isolate was added to soil at given spore counts. In the plant growth soil mixes, Acaulospora and Glomus inocula had 10000 spores $\mathrm{kg}^{-1}$ soil and Gigaspora inocula had 1000 spores $\mathrm{kg}^{-1}$ soil. In all cases, relatively good root colonization percentages were obtained for plants grown in both $\mathrm{pH}_{\mathrm{Ca}} 4$ and 5 soil. ${ }^{[9]}$ NonAM soil received $125 \mathrm{~g}$ of control inoculum $\mathrm{kg}^{-1}$ soil, which consisted of soil mix + root fragments where sudangrass had been grown under similar conditions as for AMF multiplication except with no added AMF. Each inoculum was mixed thoroughly with steam treated soil and soil mixes were put in pots $\left(2.0 \mathrm{~kg} \mathrm{pot}^{\mathrm{n} 1}\right)$ for growth of plants. 


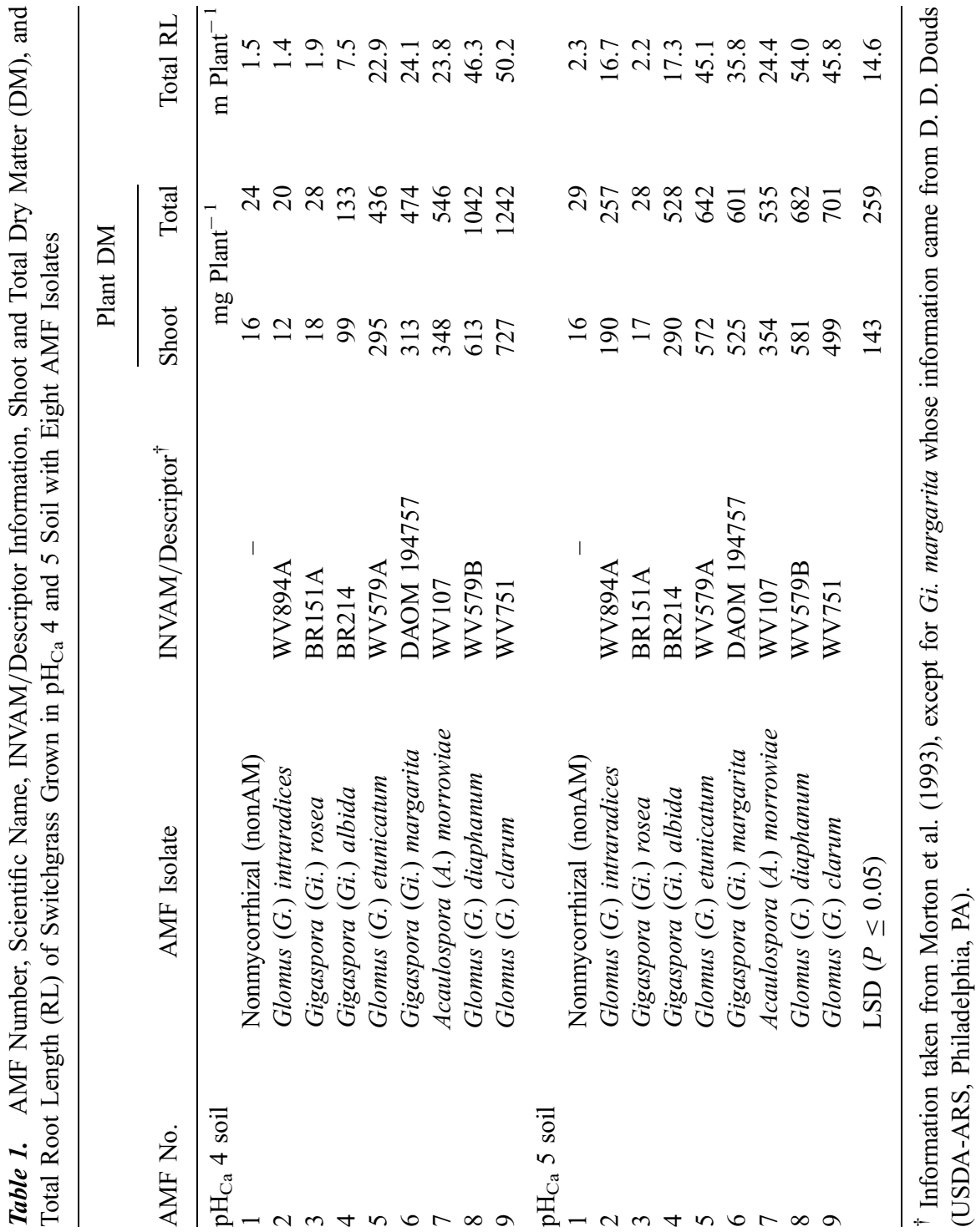


Seeds of the switchgrass cultivar "Cave-in-Rock" were surface sterilized with $70 \mathrm{mM} \mathrm{NaOCl}$ for $5 \mathrm{~min}$ and rinsed thoroughly before being sown in pots. Pots were irrigated manually with distilled water as needed during the experiment to alleviate leaching from pots, and plants did not undergo water deficit. Care was taken not to splash water or soil onto plant parts during irrigation. Plants were thinned to three pot $^{-1} 10$ days after sowing. Plants were grown for 88 days (midApril to mid-July) in a glasshouse. Additional artificial light from high-pressure sodium halide $(1000 \mathrm{~W})$ lamps was provided at $400-500 \mu \mathrm{mol} \mathrm{m}^{-2} \mathrm{~s}^{-1}$ photon flux density at plant height during cloudy days and to provide adequate light to maintain $16 \mathrm{~h}$ light periods. Throughout the experiment, temperature ranges did not vary more than $3^{\circ} \mathrm{C}$ from temperature settings of $28^{\circ} \mathrm{C}$ for the light period and $23^{\circ} \mathrm{C}$ for the dark period.

Shoots were severed from roots $\sim 1 \mathrm{~cm}$ above the soil surface at harvest, lower stalks were rinsed thoroughly with distilled water and blotted dry, and tissue dried at $60^{\circ} \mathrm{C}$ for a minimum of three $\mathrm{d}$ and weighed. Roots were thoroughly rinsed free of soil when placed on $2 \mathrm{~mm}$ screens, blotted dry, cut into $1-2 \mathrm{~cm}$ segments, thoroughly mixed, and a representative fresh weight sample collected for root length (RL) determination. Remaining roots were dried at $60^{\circ} \mathrm{C}$ similar to shoots and weighed. Total RL was determined using a Comair RL scanner (Commonwealth Aircraft Corp Ltd, Melbourne, Australia ${ }^{1}$ ). After total RL measurements were completed, root segments were dried, weighed, and dry matter (DM) included in the total plant dry weight.

Dried shoot samples were ground to pass a $0.5 \mathrm{~mm}$ screen, thoroughly mixed, and 50 to $100 \mathrm{mg}$ samples were weighed into Teflon containers. To each container with tissue, $1.0 \mathrm{~mL} 15.8 \mathrm{M} \mathrm{HNO}_{3}$ was added, and the Teflon containers placed in microwave digestion bombs (Parr Instrument Co., Moline, $\mathrm{IL}^{1}$ ). Samples were microwaved $4 \mathrm{~min}$ at $70 \%$ followed by $2 \mathrm{~min}$ at full power of $635 \mathrm{~W}$. Samples were allowed to cool in the microwave for $5 \mathrm{~min}$ before being removed for additional cooling at ambient temperature. Digested solutions were brought to a final volume of $10.0 \mathrm{~mL}$ with distilled deionized water. Solutions were filtered and stored in plastic containers at $10^{\circ} \mathrm{C}$ until analyzed for mineral elements by inductively coupled plasma spectroscopy. Nitrogen in shoot tissue was determined using a Carlo Erba elemental analyzer (Model EA1108, Carlo Erba, Milan, $\left.\operatorname{Italy}^{1}\right)$, which is a combustion-gas-chromatography procedure. ${ }^{[33]}$ Shoot mineral contents ( $\mathrm{mg}$ or $\mu \mathrm{g}$ in shoots plant ${ }^{-1}$ ) were calculated by multiplying tissue weight by mineral concentration. Mineral uptake was calculated as content of each mineral element per total RL.

The experimental design consisted of completely randomized blocks with five replications of each AMF isolate in both $\mathrm{pH}_{\mathrm{Ca}} 4$ and 5 soil. Data were

\footnotetext{
${ }^{1}$ Mention of trade names or commercial products in this publication is solely for the purpose of providing specific information and does not imply recommendation or endorsement.
} 
statistically analyzed using analysis of variance procedures, and differences among treatments and means were compared using probabilities of significance and least significant difference (LSD) values $(P \leq 0.05)$.

\section{RESULTS}

Probability differences were significant $(P \leq 0.01)$ between soil $\mathrm{pH}_{\mathrm{Ca}} 4$ and 5 and among AMF isolates for contents of each mineral element for plants grown in both $\mathrm{pH}_{\mathrm{Ca}} 4$ and 5 soil (data not shown).

\section{Mineral Contents}

Plants colonized with the various AMF isolates had large differences in shoot mineral contents (mg or $\mu \mathrm{g}$ plant $^{-1}$ ) for each element (Table 2). Even though mineral contents generally followed DM (Table 1), many of the mineral differences could not be explained exclusively by DM differences among plants. Mineral contents were generally higher in plants grown in $\mathrm{pH}_{\mathrm{Ca}} 4$ than in $\mathrm{pH}_{\mathrm{Ca}} 5$ soil. The G. etunicatum plants with lower DM compared to some other AM plants greatly benefited acquisition of many elements, especially $\mathrm{P}$, when plants were grown in $\mathrm{pH}_{\mathrm{Ca}} 4$ soil. For plants grown in both $\mathrm{pH}_{\mathrm{Ca}} 4$ and 5 soil, G. diaphanum plants were effective in reducing $\mathrm{Mn}$, and $A$. morrowiae plants had considerably lower $\mathrm{Zn}$ than many of the other AM plants.

\section{Phosphorus Uptake}

Phosphorus uptake values per RL $\left(\mathrm{P}_{\mathrm{RL}}\right)$ (mineral uptake values per $\mathrm{RL}$ are represented by the mineral symbol and the subscript RL in each case) were considerably higher for AM plants that enhanced DM and RL (Fig. 1, Table 1) compared to AM plants that did not enhance DM or RL. The AMF isolates that did not increase DM or RL above that of the nonAM plants were Gi. rosea and $G$. intraradices plants grown in $\mathrm{pH}_{\mathrm{Ca}} 4$ soil and Gi. rosea plants grown in $\mathrm{pH}_{\mathrm{Ca}} 5$ soil. That is, $\sim 2$-fold differences in $\mathrm{P}_{\mathrm{RL}}$ were noted among AM plants that had enhanced $\mathrm{DM}$ in both $\mathrm{pH}_{\mathrm{Ca}} 4$ and 5 soil. Differences between the highest $\mathrm{P}_{\mathrm{RL}}$ values for $\mathrm{AM}$ plants compared to nonAM plants was 18 -fold for plants grown in $\mathrm{pH}_{\mathrm{Ca}} 4$ soil and 9-fold for plants grown in $\mathrm{pH}_{\mathrm{Ca}} 5$ soil. Overall, $\mathrm{AM}$ plants grown in $\mathrm{pH}_{\mathrm{Ca}} 4$ soil had slightly higher $\mathrm{P}_{\mathrm{RL}}$ values than plants grown in $\mathrm{pH}_{\mathrm{Ca}} 5$ soil. The AM plants with highest $\mathrm{P}_{\mathrm{RL}}$ values were G. etunicatum and Gi. margarita plants grown in $\mathrm{pH}_{\mathrm{Ca}} 4$ soil and Gi. margarita plants grown in $\mathrm{pH}_{\mathrm{Ca}} 5$ soil. Highest $\mathrm{P}_{\mathrm{RL}}$ values were not related to highest shoot $\mathrm{P}$ content or greatest amount of $\mathrm{RL}$ or DM. 


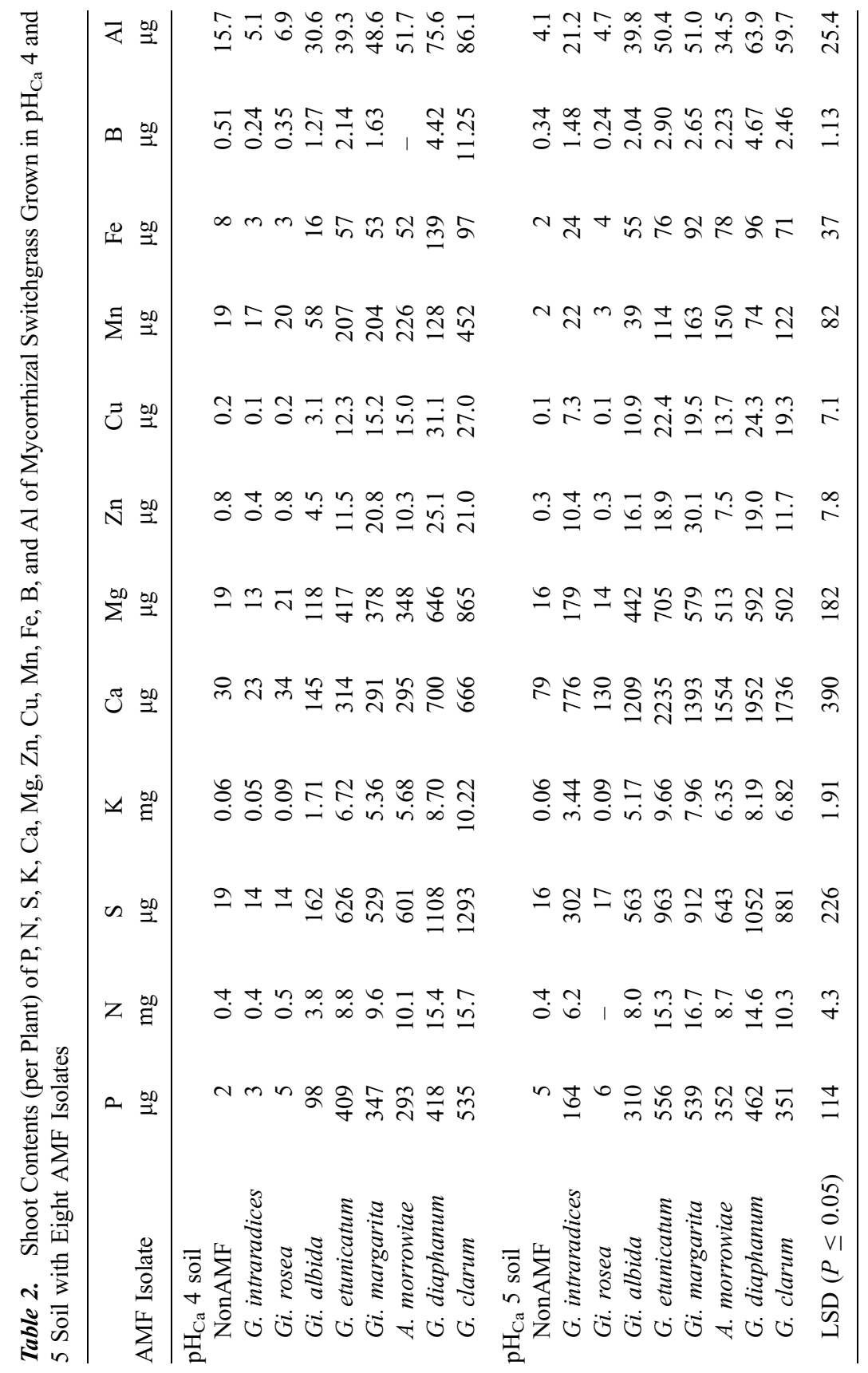



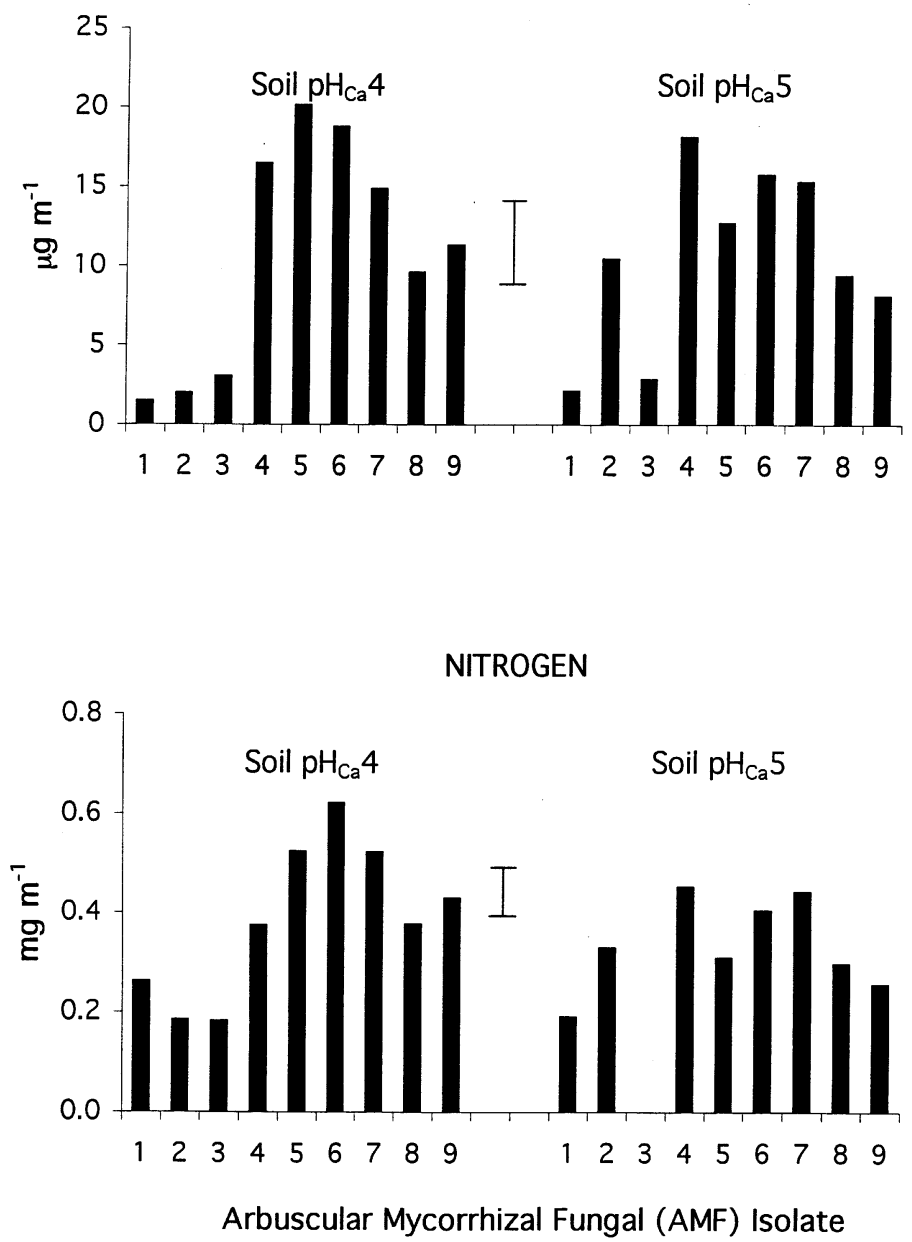

Figure 1. Phosphorus and nitrogen uptake per root length (RL) of switchgrass grown in $\mathrm{pH}_{\mathrm{Ca}} 4$ and 5 soil with eight AMF isolates. See Table 1 for numbers identifying AMF isolates. The $I$ in graphs represents LSD values $(P \leq 0.05)$.

\section{Nitrogen and Sulfur Uptake}

The $\mathrm{N}_{\mathrm{RL}}$ values varied extensively among $\mathrm{AM}$ plants, and $\mathrm{AM}$ plants grown in $\mathrm{pH}_{\mathrm{Ca}} 4$ soil generally had higher $\mathrm{N}_{\mathrm{RL}}$ values than $\mathrm{AM}$ plants grown in $\mathrm{pH}_{\mathrm{Ca}} 5$ soil (Fig. 1). Differences between $\mathrm{N}_{\mathrm{RL}}$ values for nonAM and AM plants 
with the highest value were only $\sim 2.0-2.5$-fold for plants grown in both $\mathrm{pH}_{\mathrm{Ca}} 4$ and 5 soil. However, a couple of AM plants had considerably higher $\mathrm{N}_{\mathrm{RL}}$ values in $\mathrm{pH}_{\mathrm{Ca}} 4$ than in $\mathrm{pH}_{\mathrm{Ca}} 5$ soil. Even though wide differences were noted among $\mathrm{AM}$ plants for $\mathrm{S}_{\mathrm{RL}}$ values for most $\mathrm{AM}$ plants, plants grown in $\mathrm{pH}_{\mathrm{Ca}} 4$ and 5 soil had relatively similar values (Fig. 2).
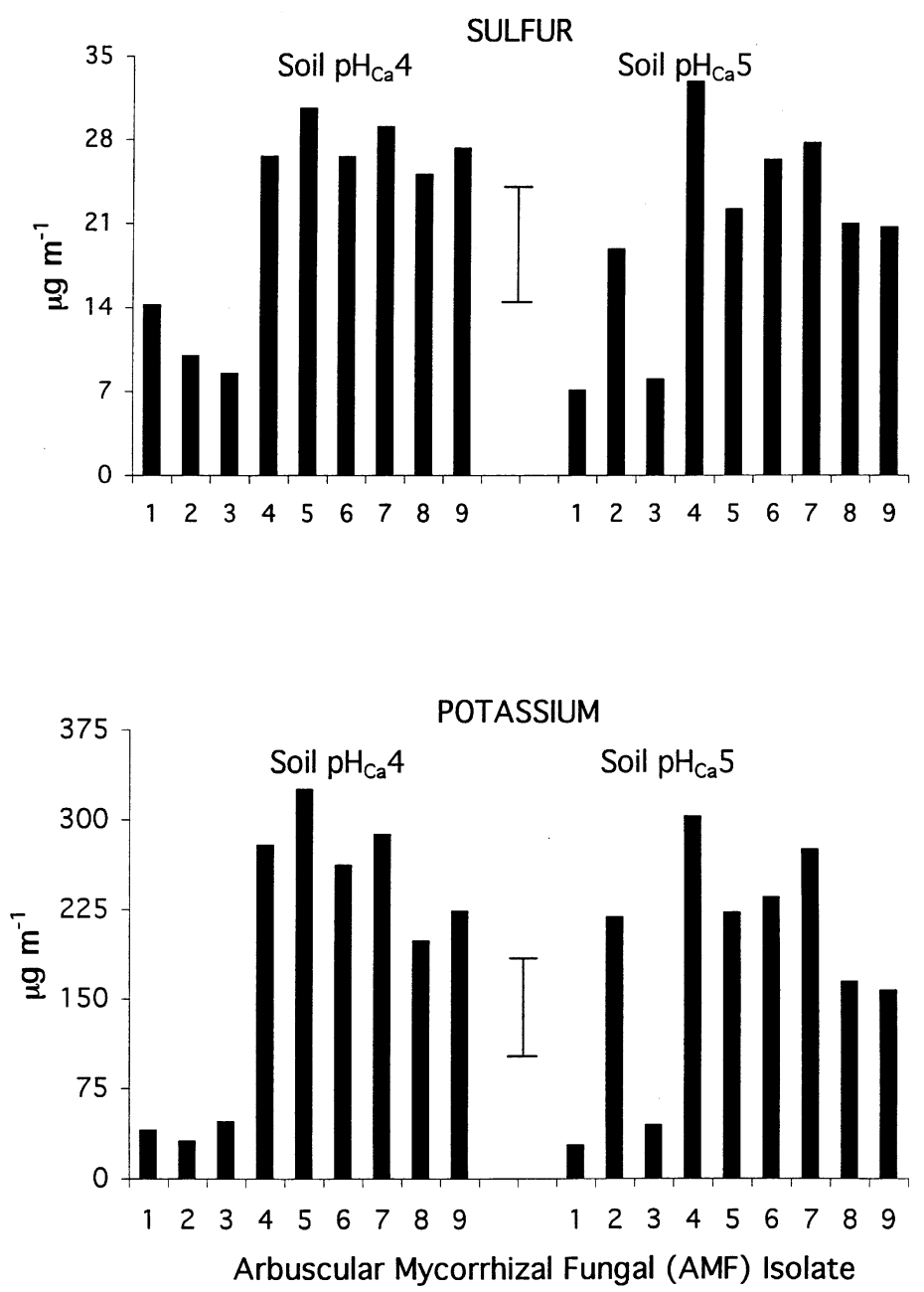

Figure 2. Sulfur and potassium uptake per root length (RL) of switchgrass grown in $\mathrm{pH}_{\mathrm{Ca}} 4$ and 5 soil with eight AMF isolates. See Table 1 for numbers identifying AMF isolates. The $I$ in graphs represents LSD values $(P \leq 0.05)$. 


\section{Potassium, Calcium, and Magnesium Uptake}

The AM plants that had enhanced RL and DM had considerably higher $\mathrm{K}_{\mathrm{RL}}$ values compared to nonAM and AM plants that did not enhance RL or DM in both $\mathrm{pH}_{\mathrm{Ca}} 4$ and 5 soil (Fig. 2). Differences in $\mathrm{K}_{\mathrm{RL}}$ values among the AM plants that enhanced growth in both $\mathrm{pH}_{\mathrm{Ca}} 4$ and 5 soil were relatively narrow ( $<2$-fold). The $\mathrm{Ca} \mathrm{Ca}_{\mathrm{RL}}$ values were generally lower for $\mathrm{AM}$ plants grown in $\mathrm{pH}_{\mathrm{Ca}} 4$ than in $\mathrm{pH}_{\mathrm{Ca}} 5$ soil (Fig. 3). Differences among $\mathrm{AM}$ plants for $\mathrm{Ca}_{\mathrm{RL}}$
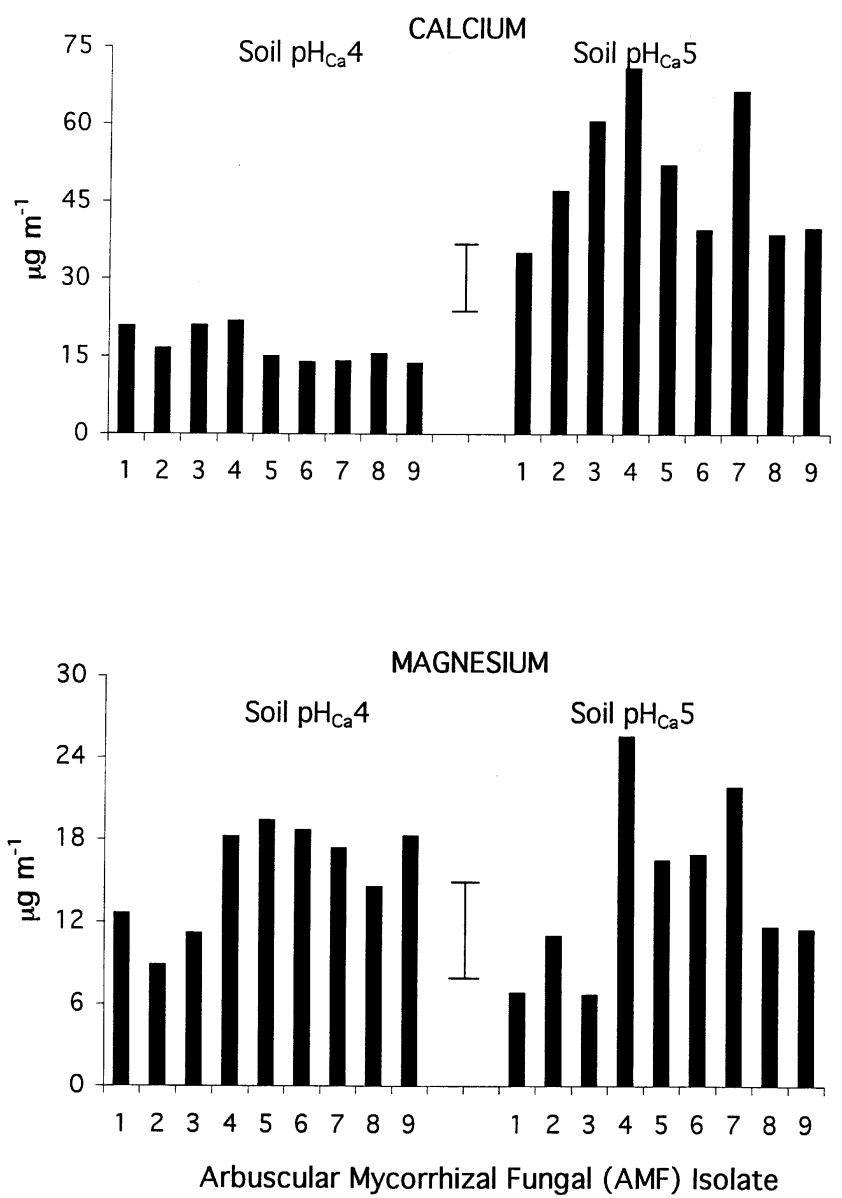

Figure 3. Calcium and magnesium uptake per root length (RL) of switchgrass grown in $\mathrm{pH}_{\mathrm{Ca}} 4$ and 5 soil with eight AMF isolates. See Table 1 for numbers identifying AMF isolates. The $I$ in graphs represents LSD values $(P \leq 0.05)$. 
values were relatively narrow for plants grown in $\mathrm{pH}_{\mathrm{Ca}} 4$ soil and fairly broad for plants grown in $\mathrm{pH}_{\mathrm{Ca}} 5$ soil, and $\mathrm{Ca}_{\mathrm{RL}}$ values were relatively narrow for the various $\mathrm{AM}$ plants. Differences among $\mathrm{AM}$ plants for $\mathrm{Mg}_{\mathrm{RL}}$ values when grown in $\mathrm{pH}_{\mathrm{Ca}} 4$ soil were relatively narrow compared to $\mathrm{AM}$ plants grown in $\mathrm{pH}_{\mathrm{Ca}} 5$ soil (Fig. 3).
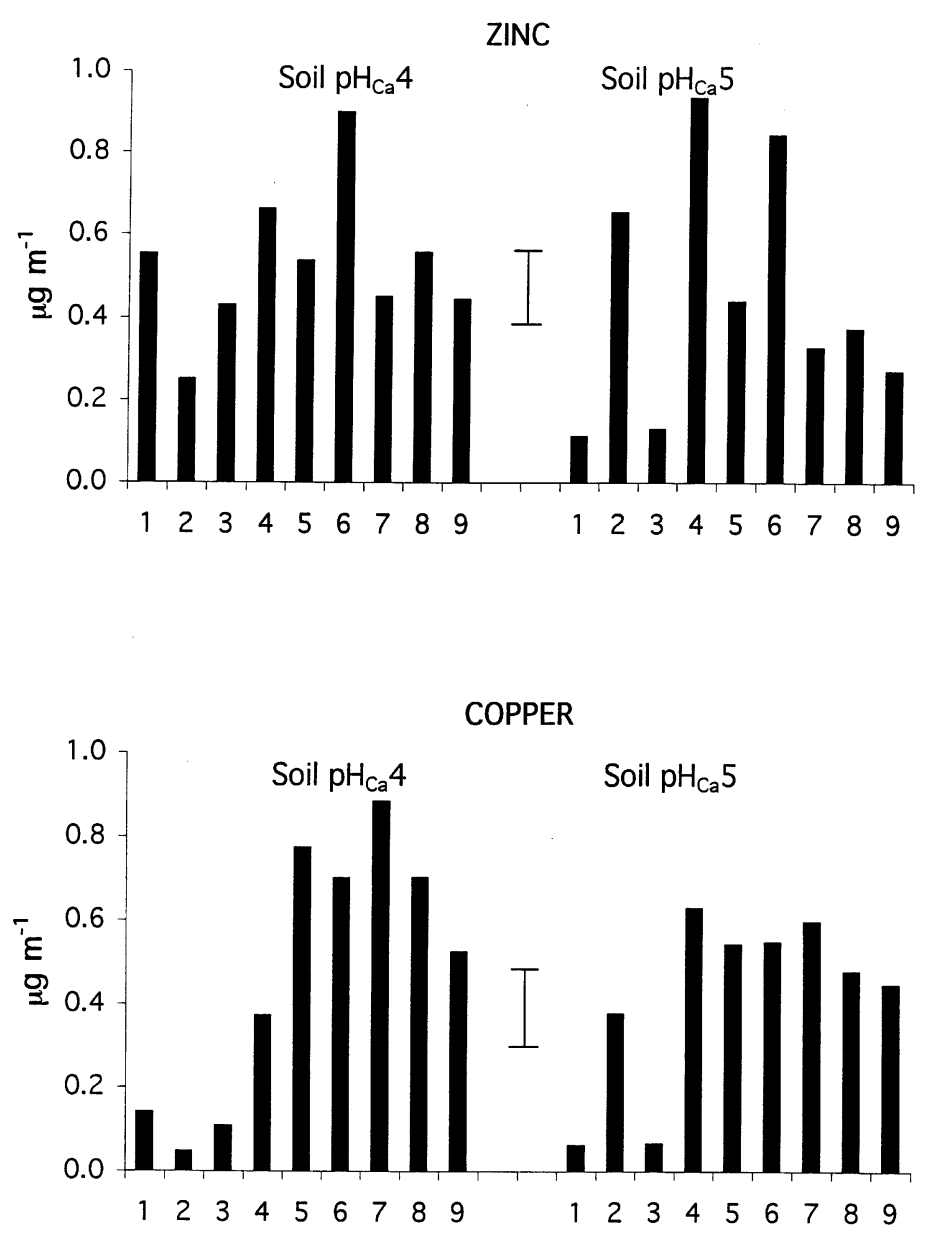

Arbuscular Mycorrhizal Fungal (AMF) Isolate

Figure 4. Zinc and copper uptake per root length (RL) of switchgrass grown in $\mathrm{pH}_{\mathrm{Ca}} 4$ and 5 soil with eight AMF isolates. See Table 1 for numbers identifying AMF isolates. The I in graphs represents LSD values $(P \leq 0.05)$. 


\section{Micronutrient Uptake}

Considerable differences were noted for the $\mathrm{Zn}_{\mathrm{RL}}$ and $\mathrm{Cu}_{\mathrm{RL}}$ values of $\mathrm{AM}$ plants grown in both $\mathrm{pH}_{\mathrm{Ca}} 4$ and 5 soil (Fig. 4). The $\mathrm{Mn}_{\mathrm{RL}}, \mathrm{Fe}_{\mathrm{RL}}$, and $\mathrm{B}_{\mathrm{RL}}$ values were consistently higher for $\mathrm{AM}$ plants grown in $\mathrm{pH}_{\mathrm{Ca}} 4$ than in $\mathrm{pH}_{\mathrm{Ca}} 5$ soil, and differences among AM plants grown in $\mathrm{pH}_{\mathrm{Ca}} 4$ soil were larger compared to plants grown in $\mathrm{pH}_{\mathrm{Ca}} 5$ soil (Figs. 5 and 6). These $\mathrm{Mn}_{\mathrm{RL}}, \mathrm{Fe}_{\mathrm{RL}}$, and $\mathrm{B}_{\mathrm{RL}}$ values
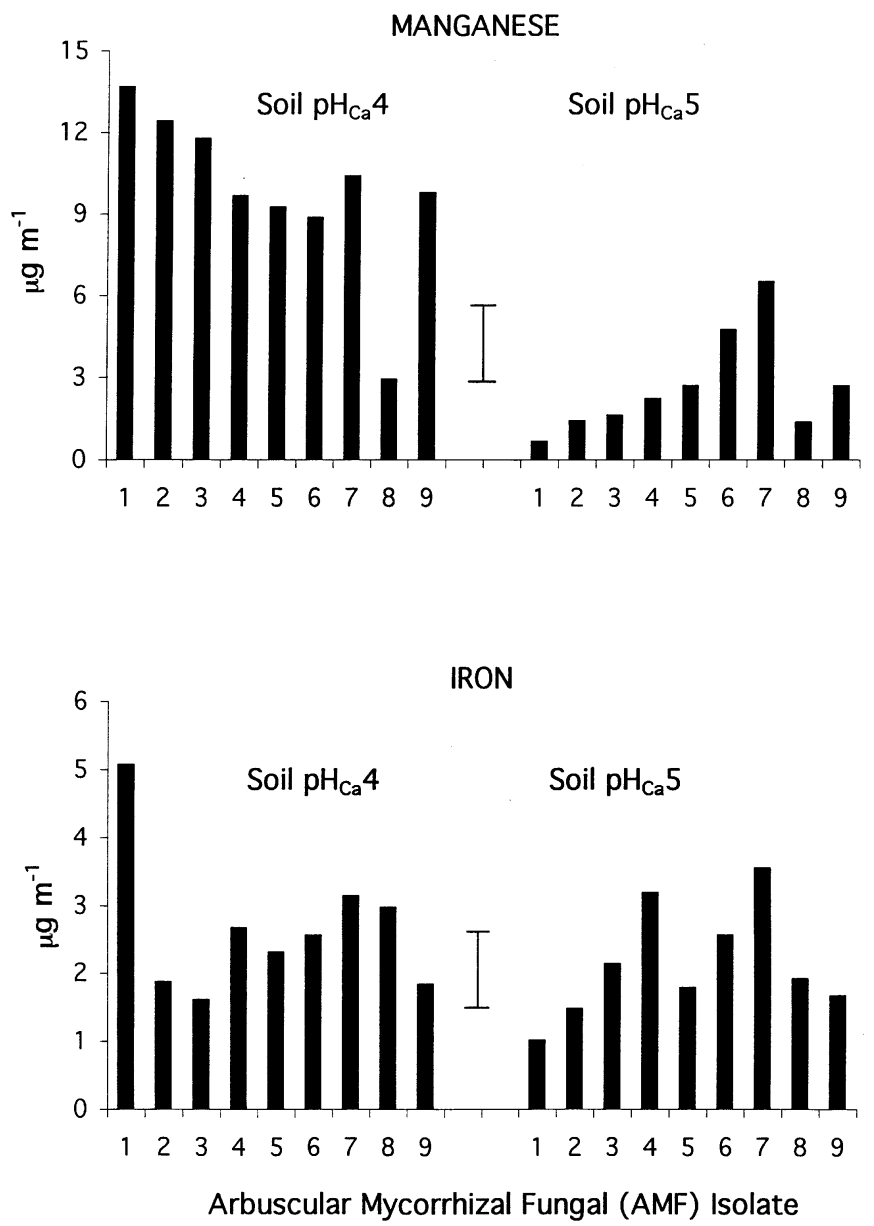

Figure 5. Manganese and iron uptake per root length (RL) of switchgrass grown in $\mathrm{pH}_{\mathrm{Ca}}$ 4 and 5 soil with eight AMF isolates. See Table 1 for numbers identifying AMF isolates. The I in graphs represents LSD values $(P \leq 0.05)$. 

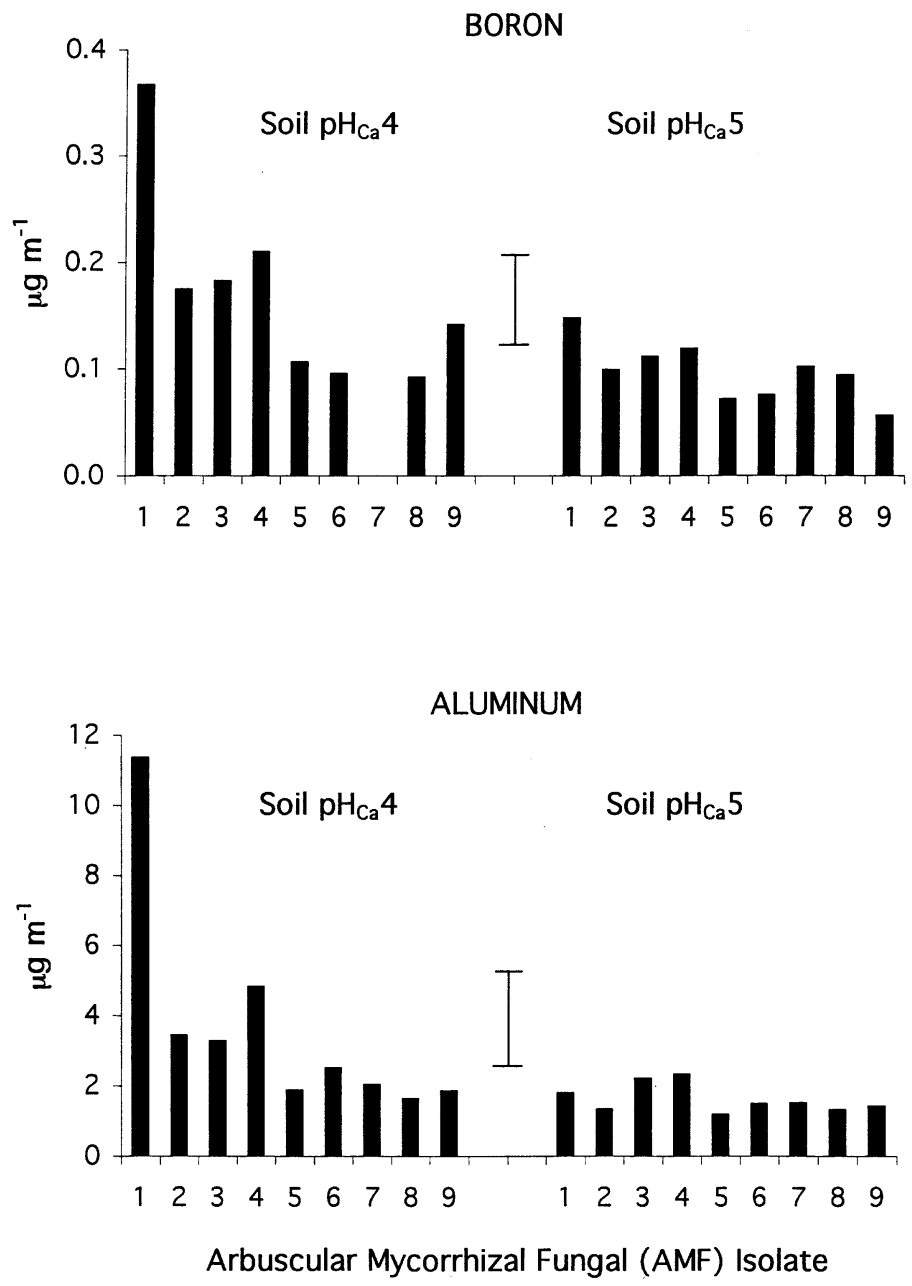

Figure 6. Boron and aluminum uptake per root length (RL) of switchgrass grown in $\mathrm{pH}_{\mathrm{Ca}} 4$ and 5 soil with eight AMF isolates. See Table 1 for numbers identifying AMF isolates. The $I$ in graphs represents LSD values $(P \leq 0.05)$.

were usually highest for nonAM or AM plants that did not enhance DM and RL. That is, many AM plants had restricted uptake of $\mathrm{Mn}, \mathrm{Fe}$, and $\mathrm{B}$. The Gi. rosea plants had highest $\mathrm{Fe}_{\mathrm{RL}}$ values when plants were grown in $\mathrm{pH}_{\mathrm{Ca}} 4$ soil. Except for $\mathrm{Cu}_{\mathrm{RL}}$, nonAM plants had the highest or nearly highest values of the other micronutrients. 
Aluminum Uptake

The $\mathrm{Al}_{\mathrm{RL}}$ values were markedly higher for $\mathrm{G} i$. rosea plants (did not enhance DM or RL) than for the other AM plants (enhanced DM and RL) grown in $\mathrm{pH}_{\mathrm{Ca}} 4$ soil (Fig. 6). Most $\mathrm{AM}$ plants restricted uptake of Al. The AM plants grown in $\mathrm{pH}_{\mathrm{Ca}} 5$ soil had considerably lower $\mathrm{Al}_{\mathrm{RL}}$ values than $\mathrm{AM}$ plants grown in $\mathrm{pH}_{\mathrm{Ca}} 4$ soil.

\section{DISCUSSION}

A major effect that many of the AMF isolates used in this study had on this switchgrass cultivar grown in acidic soil was to increase RL (Table 1). Plants with greater amounts of RL should have had greater ability to obtain mineral nutrients from existing volumes of soil compared to plants with lower amounts of RL, because more surface area would be available for acquiring minerals. However, the effect of AMF hyphae per se at increasing root surface area available to access mineral nutrients is unknown, since hyphal length/mass in soil was not determined. It is most likely that AMF hyphae were important in increasing surface area for mineral acquisition. One important effect many acidic soils have on roots is to inhibit elongation because of toxic elements like $\mathrm{Al}$ and Mn. ${ }^{[1]}$ Excess Al may also inhibit hyphal elongation. ${ }^{[34]}$ As such, the Al and possibly Mn contained in the acidic soil used in this study might have had major effects on both host root and AMF hyphal elongation. It was evident that this acidic soil inhibited RL of the switchgrass grown without AMF (Table 1). This batch of Lily soil had high Al ( $88 \%$ of macronutrient cationic exchange) and low $\mathrm{P}$ (3.1 $\mathrm{mg} \mathrm{kg}^{-1}$ soil), and should have imposed relatively severe Al toxicity and/or P deficiency on plants. Where this soil was used in other studies, Lily soil imposed fairly severe Al toxicity on plants. ${ }^{[9,35]}$ Most of the AMF isolates used in this study effectively alleviated some growth inhibiting stresses that this soil imposed on the switchgrass cultivar grown, and enhanced both $\mathrm{RL}$ and DM (Table 1). Two AMF isolates were ineffective in $\mathrm{pH}_{\mathrm{Ca}} 4$ soil (G. intraradices and Gi. rosea) and one in $\mathrm{pH}_{\mathrm{Ca}} 5$ soil (Gi. rosea). Two AMF isolates that were especially effective in both $\mathrm{pH}_{\mathrm{Ca}} 4$ or 5 soil were $G$. clarum and $G$. diaphanum, with $G$. etunicatum also being highly effective in $\mathrm{pH}_{\mathrm{Ca}} 5$ soil. An interesting response of $\mathrm{AMF}$ on increasing $\mathrm{RL}$ was that most isolates were more effective in $\mathrm{pH}_{\mathrm{Ca}} 4$ than in $\mathrm{pH}_{\mathrm{Ca}} 5$ soil, so these AMF isolates likely had relatively good tolerance to soil acidity. This might be expected since most isolates were isolated from acidic soils. ${ }^{[31]}$

With increased RL, AM plants should have been able to acquire higher concentrations and/or contents of mineral nutrients essential to plant growth. 
Higher shoot mineral concentrations ${ }^{[12]}$ and contents (Table 2) were noted for many of the AM plants, and enhanced shoot DM could not account for all of the mineral content increases noted. The marked differences among AM plants for RL might indicate that AMF could have considerably different effects on plant acquisition of mineral nutrients. This led us to consider mineral uptake relative to RL by the AM plants to evaluate differences for this trait to help explain some of the differences noted.

Information about host plant $\mathrm{P}$ (and other mineral nutrient) uptake associated with RL is limited. Since $\mathrm{P}$ is the most frequently reported mineral nutrient enhanced in AM plants, ${ }^{[36-38]}$ considerable amounts of information are available about uptake and transport of $\mathrm{P}$ in $\mathrm{AM}$ plants. ${ }^{[39-41]}$ In addition, information about such factors as growth media $\mathrm{P}$ supply, plant $\mathrm{P}$ demand, mycorrhizal influence on growth and plant $\mathrm{P}$ acquisition and use, and $\mathrm{P}$ uptake associated with hyphae is also extensive. ${ }^{[39,40]}$

The $\mathrm{P}_{\mathrm{RL}}$ values reported for $\mathrm{AM}$ and nonAM plants of a few studies have been compared, and AM plants generally had 2.0-2.5-fold higher P uptake than nonAM plants. ${ }^{[29]}$ Similar differences were noted for AM and nonAM maize and soybean grown in two soils with $\mathrm{pH} 4.7,5.6$, and 6.4. ${ }^{[17]}$ Large differences between $\mathrm{AM}$ and nonAM plants for $\mathrm{P}_{\mathrm{RL}}$ values might be expected, but information comparing $\mathrm{AMF}$ isolate differences for mineral uptake is scarce. One such study reported $S$. calospora, Glomus sp., and A. laevis subterraneum clover ( $\mathrm{pH}$ 5.3) to have 1.9-2.5-fold differences, with $S$. calospora plants being highest and Glomus sp. plants being lowest. ${ }^{[42]}$

Calculations from data in the literature also indicated that AMF isolates had mineral uptake differences associated with RL. For example, $\mathrm{P}_{\mathrm{RL}}$ values for $S$. calospora subterraneum clover grown with varied levels of $\mathrm{P}$ were consistently lower than Glomus sp. plants, but mineral uptake was even higher when Glomus sp. and S. calospora inocula were combined. ${ }^{[43]}$ However, $\mathrm{P}_{\mathrm{RL}}$ differences between Glomus sp. and G. caledonium cucumber (Cucumis sativus L.) were not significantly different. ${ }^{[4]}$ Glomus sp. (G. etunicatum-like) and Gi. margarita cowpea (Vigna unguiculata L.), pigeonpea [Cajanus cajan (L.) Millsp.], and groundnut (Arachis hypogaea L.) grown in fertile topsoil and infertile subsoil at pH 6.0 had wide differences for $\mathrm{P}_{\mathrm{RL}}$ values. ${ }^{[45]}$ Glomus sp. plants consistently had higher $\mathrm{P}_{\mathrm{RL}}$ values than Gi. margarita plants grown in both a topsoil ( $72 \mathrm{mg} \mathrm{P} \mathrm{kg}^{-1}$ soil) and a subsoil $\left(<0.1 \mathrm{mg} \mathrm{P} \mathrm{kg}^{-1}\right.$ soil). Similar differences in $\mathrm{P}_{\mathrm{RL}}$ values were noted for AM cowpea and groundnut grown in a topsoil, but not for AM pigeonpea. In other studies, G. etunicatum, G. intraradices, and G. diaphanum maize grown in two acidic soils $\left(\mathrm{pH}_{\mathrm{Ca}} 4.2\right.$ and 4.6) had no differences in $\mathrm{P}_{\mathrm{RL}}$ values. ${ }^{[10]}$

$\mathrm{Zn}_{\mathrm{RL}}$ values were higher for $S$. calospora subterraneum clover than for either Glomus sp. or A. laevis plants, while A. laevis plants had slightly higher $\mathrm{Zn}_{\mathrm{RL}}$ values than Glomus sp. plants. ${ }^{[46]}$ Glomus sp. cowpea and groundnut 
consistently had higher $\mathrm{N}, \mathrm{K}, \mathrm{Ca}, \mathrm{Mg}, \mathrm{Zn}, \mathrm{Cu}$, and $\mathrm{Fe}$ uptake per RL than did Gi. margarita plants grown in fertile topsoil and infertile subsoil. ${ }^{[45]}$ Only $\mathrm{Mn}_{\mathrm{RL}}$ values were higher in Gi. margarita than in Glomus sp. plants grown in these soil layers. Similar results were noted for Gi. margarita and Glomus sp. pigeonpea grown in the subsoil, but only $\mathrm{Zn}_{\mathrm{RL}}, \mathrm{Cu}_{\mathrm{RL}}, \mathrm{Fe}_{\mathrm{RL}}$, and $\mathrm{Mn}_{\mathrm{RL}}$ values were higher in Glomus sp. than in Gi. margarita plants grown in the topsoil. The $\mathrm{N}_{\mathrm{RL}}, \mathrm{K}_{\mathrm{RL}}, \mathrm{Ca}_{\mathrm{RL}}$, and $\mathrm{Mg}_{\mathrm{RL}}$ values were similar for $\mathrm{Gi}$. margarita and Glomus sp. pigeonpea grown in the topsoil. G. intraradices, G. etunicatum, and G. diaphanum maize grown in acidic soil had similar $\mathrm{N}_{\mathrm{RL}}, \mathrm{S}_{\mathrm{RL}}, \mathrm{K}_{\mathrm{RL}}, \mathrm{Ca} \mathrm{a}_{\mathrm{RL}}$, $\mathrm{Mg}_{\mathrm{RL}}, \mathrm{Zn}_{\mathrm{RL}}, \mathrm{Cu}_{\mathrm{RL}}, \mathrm{Mn}_{\mathrm{RL}}, \mathrm{Fe}_{\mathrm{RL}}$, and $\mathrm{B}_{\mathrm{RL}}$ values, but G. intraradices plants consistently had higher mineral uptake values per RL than G. etunicatum and G. diaphanum plants. ${ }^{[10]}$

Results of the study reported here indicated that the AMF isolates used had dramatic effects on plant responses for uptake of mineral nutrients by the switchgrass grown in low pH Lily soil. Mineral nutrient uptake per RL was dramatically different among AM plants, and those AMF isolates that enhanced DM and RL consistently had higher mineral uptake per RL than AM plants that did not have enhanced DM or RL. Mineral uptake per RL of nonAM plants was similar to that of AM plants that did not enhance DM or RL. Some how, AMF were providing benefits to plants beyond that which could be accounted for by increased RL. These benefits could have possibly come from increased AMF hyphal lengths and/or stimulated activity of mineral nutrient uptake and transport. Differences among hyphae of various AMF have been reported for $P$ uptake. ${ }^{[42,44,47]}$

Most of the AMF isolates used in this study were effective in enhancing uptake of mineral nutrients essential to plant growth and restricting elements that may become toxic. As might be expected, the mineral nutrient to be enhanced most extensively in AM plants was $\mathrm{P}$ concentration ${ }^{[10]}$ and content (Table 2), but uptake of many of the other essential mineral nutrients, especially $\mathrm{N}, \mathrm{S}, \mathrm{K}$, and $\mathrm{Mg}$, were also greatly enhanced (Figs. 1-3). Even though many AMF were effective in enhancing uptake of mineral nutrients, $G$. etunicatum was especially effective in so doing. Although this acidic Lily soil has potential to impose severe $\mathrm{Al}$, and possibly $\mathrm{Mn}$, toxicities on plants, these toxicities were alleviated by inoculation of switchgrass with many of the AMF isolates used. The $G$. diaphanum was especially effective in reducing $\mathrm{Mn}$ uptake, A. morrowiae reduced $\mathrm{Zn}$, and several AMF isolates were effective in restricting $\mathrm{Al}$ uptake. The $\mathrm{AMF}$ isolates that were not particularly effective in $\mathrm{pH}_{\mathrm{Ca}} 4$ soil were G. rosea and G. intraradices, and Gi. rosea in $\mathrm{pH}_{\mathrm{Ca}} 5$ soil. Appropriate AMF have considerable ability to improve tolerance of many plants to acidic soil with $\mathrm{pH}_{\mathrm{Ca}}$ as low as 4 by enhancing acquisition of mineral nutrients essential to growth and restricting toxic elements like $\mathrm{Al}$ and $\mathrm{Mn}$. 


\section{ACKNOWLEDGMENTS}

The technical assistance of Ms. S. K. Zeto was greatly appreciated. A special thanks is extended to Dr. R. W. Zobel who provided valuable discussion and many contributions in preparation of this manuscript.

\section{REFERENCES}

1. Foy, C.D. Soil Chemical Factors Limiting Plant Root Growth. Adv. Soil Sci. 1992, 19, 87-149.

2. Marschner, H. Mechanisms of Adaptation of Plants to Acid Soils. Plant Soil 1991, 134, 1-20.

3. Bethlenfalvay, G.J. Mycorrhizae in Crop Productivity. In Mycorrhizae in Sustainable Agriculture; Bethlenfalvay, G.J., Linderman, R.G., Eds.; Am. Soc. Agron.: Madison, WI, 1992; Spec. Publ. No. 54, 1-27.

4. Linderman, R.G. Vesicular-Arbuscular Mycorrhizae and Soil Microbial Interactions. In Mycorrhizae in Sustainable Agriculture; Bethlenfalvay, G.J., Linderman, R.G., Eds.; Am. Soc. Agron.: Madison, WI, 1992; Spec. Publ. No. 54, 45-70.

5. Linderman, R.G. Role of VAM Fungi in Biocontrol. In Mycorrhizae and Plant Health; Pfleger, F.L., Linderman, R.G., Eds.; Am. Phytopath. Soc.: St Paul, MN, 1994; 1-25.

6. Sieverding, E. Vesicular-Arbuscular Mycorrhiza Management in Tropical Agrosystems; Deutsche Gesellschaft Technische Zusammenarbeit: Eschborn, Germany, 1991.

7. Sylvia, D.M.; Williams, S.E. Vesicular-Arbuscular Mycorrhizae and Environmental Stress. In Mycorrhizae in Sustainable Agriculture; Bethlenfalvay, G.J., Linderman, R.G., Eds.; Am. Soc. Agron.: Madison, WI, 1992; Spec. Publ. No. 54, 101-124.

8. Bethlenfalvay, G. J.; Franson, R.L. Manganese Toxicity Alleviated by Mycorrhizae in Soybean. J. Plant Nutr. 1989, 12, 953-970.

9. Clark, R.B.; Zeto, S.K. Growth and Root Colonization of Mycorrhizal Maize Grown on Acid and Alkaline Soil. Soil Biol. Biochem. 1996, 28, 1505-1511.

10. Clark, R.B.; Zeto, S.K. Mineral Acquisition by Mycorrhizal Maize Grown on Acid and Alkaline Soil. Soil Biol. Biochem. 1996, 28, 1495-1503.

11. Clark, R.B.; Zeto, S.K.; Zobel, R.W. Arbuscular Mycorrhizal Fungal Isolate Effectiveness on Growth and Root Colonization of Panicum virgatum in Acidic Soil. Soil Biol. Biochem. 1999, 31, 1757-1763.

12. Clark, R.B.; Zobel, R.W.; Zeto, S.K. Effect of Mycorrhizal Fungal Isolates on Mineral Acquisition by Panicum virgatum in Acidic Soil. Mycorrhiza 1999, 9, 167-176. 
13. Howeler, R.H.; Sieverding, E.; Saif, S.R. Practical Aspects of Mycorrhizal Technology in Some Tropical Crops and Pastures. Plant Soil 1987, 100, 249-283.

14. Maddox, J.J.; Soileau, J.M. Effect of Phosphate Fertilization, Lime Amendments, and Inoculation with VA-Mycorrhizal Fungi on Soybeans in an Acid Soil. Plant Soil 1991, 134, 83-93.

15. Medeiros, C.A.B.; Clark, R.B.; Ellis, J.R. Effects of Excess Aluminum on Mineral Uptake in Mycorrhizal Sorghum. J. Plant Nutr. 1994, 17, 1399-1416.

16. Medeiros, C.A.B.; Clark, R.B.; Ellis, J.R. Effects of Excess Manganese on Mineral Uptake in Mycorrhizal Sorghum. J. Plant Nutr. 1994, 17, 2203-2219.

17. Nurlaeny, N.; Marschner, H.; George, E. Effects of Liming and Mycorrhizal Colonization on Soil Phosphate Depletion and Phosphate Uptake by Maize (Zea mays L.) and Soybean (Glycine max L.) Grown in Two Tropical Acid Soils. Plant Soil 1996, 181, 275-285.

18. Raju, P.S.; Clark, R.B.; Ellis, J.R.; Maranville, J.W. Effects of VA Mycorrhizae on Growth and Mineral Uptake of Sorghum Grown at Varied Levels of Soil Acidity. Commun. Soil Sci. Plant Anal. 1988, 19, 919-931.

19. Saif, S.R. Growth Responses of Tropical Forage Plant Species to VesicularArbuscular Mycorrhizae. Plant Soil 1987, 97, 25-35.

20. Schenck, N.C.; Siqueira, J.O. Ecology of VA Mycorrhizal Fungi in Temperate Agroecosystems. In Mycorrhizae in the Next Decade, Practical Applications and Research Priorities; Sylvia, D.M., Hung, L.L., Graham, J.H., Eds.; Univ. Florida: Gainesville, FL, 1987; 2-4.

21. Clark, R.B.; Duncan, R.R. Selection of Plants to Tolerate Soil Salinity, Acidity, and Mineral Deficiencies. In International Crop Science; Buxton, D.R., Shibles, R., Forsberg, R.A., Blad, B.L., Asay, K.H., Paulsen, G.M., Wilson, R.F., Eds.; Crop Sci. Soc. Am.: Madison, WI, 1992; Vol. I, 371-379.

22. Duncan, R.R. Acid Soil Tolerance Breeding in Sorghum. Adv. Agron. (India) 1991, 1, 71-79.

23. Duncan, R.R.; Baligar, V.C. Genetics, Breeding, and Physiological Mechanism of Nutrient Uptake and Use Efficiency. In Crops as Enhancers of Nutrient Use; Baligar, V.C., Duncan, R.R., Eds.; Academic Press: San Diego, CA, 1990; 3-35.

24. Foy, C.D. Plant Adaptation to Mineral Stress in Problem Soils. Iowa State J. Res. 1983, 57, 339-354.

25. Lambais, M.R.; Cardoso, E.J.B.N. Response of Stylosanthes guianensis to Endomycorrhizal Fungi Inoculation as Affected by Lime and Phosphorus Applications. II. Nutrient Uptake. Plant Soil 1993, 150, 109-116.

26. Medeiros, C.A.B.; Clark, R.B.; Ellis, J.R. Growth and Nutrient Uptake of Sorghum Cultivated with Vesicular-Arbuscular Mycorrhiza Isolates at Varying pH. Mycorrhiza 1994, 4, 185-191. 
27. Saggin, O.J., Jr.; Siqueira, J.O. Evaluation of the Symbiotic Effectiveness of Endomycorrhizal Fungi for Coffee Tree. R. Brasil Ci. Solo (Campinas) 1995, 19, 221-228.

28. Saggin, O.J., Jr.; Siqueira, J.O.; Guimarâes, P.T.G.; Oliveira, E. Inoculation of Coffee Tree with Different Mycorrhizal Fungi: Effects on Seedling Raising and on Outplants Growth in Fumigated Soil. R. Brasil Ci. Solo (Campinas) 1995, 19, 213-220.

29. Tinker, P.B.; Jones, M.D.; Durall, D.M. Functional Comparison of Ecto- and Endomycorrhizas. In Mycorrhizas in Ecosystems; Read, D.J., Lewis, D.H., Fitter, A.H., Alexander, I.J., Eds.; Comm. Agric. Bur. (CAB) Int.: Wellingsford, UK, 1992; 303-310.

30. Jakobsen, I.; Abbott, L.K.; Robson, A.D. External Hyphae of VesicularArbuscular Mycorrhizal Fungi Associated with Trifolium subterraneum L. 1. Spread of Hyphae and Phosphorus Inflow into Roots. New Phytol. 1992, 120, 371-380.

31. Morton, J.B.; Bentivenga, S.P.; Wheeler, W.W. Germ Plasm in the International Collection of Arbuscular and Vesicular-Arbuscular Mycorrhizal Fungi (INVAM) and Procedures for Culture Development, Documentation and Storage. Mycotaxon 1993, 48, 491-528.

32. Page, A.L.; Miller, R.H.; Keeney, D.R. (Eds.). Methods of Soil Analysis. Part 2. Chemical and Microbiological Properties, 2nd Ed.; Am. Soc. Agron. and Soil Sci. Soc. Am.: Madison, WI, 1982; Spec. Publ. No. 9.

33. Pella, E.; Colombo, B. Study of Carbon, Hydrogen, and Nitrogen Determination by Combustion-Gas-Chromatography; Mikrochim. Acta [Wien], Springer-Verlag: Berlin, 1973, 697-719.

34. Bartolome-Esteban, H.; Schenck, N.C. Spore Germination and Hyphal Growth of Arbuscular Mycorrhizal Fungi in Relation to Soil Aluminum Saturation. Mycologia 1994, 86, 217-226.

35. Clark, R.B.; Zeto, S.K.; Ritchey, K.D.; Baligar, V.C. Growth of Forages on Acid Soil Amended with Flue Gas Desulfurization By-Products. Fuel 1997, 76, 771-775.

36. Bolan, N.S. A Critical Review on the Role of Mycorrhizal Fungi in the Uptake of Phosphorus by Plants. Plant Soil 1991, 134, 187-207.

37. Hetrick, B.A.D. Acquisition of Phosphorus by VA Mycorrhizal Fungi and the Growth Responses of Their Host Plants. In Nitrogen, Phosphorus and Sulphur Utilization by Fungi; Boddy, L., Marchant, R., Reid, D.J., Eds.; Cambridge Univ. Press: New York, 1989; 205-226.

38. Marschner, H.; Dell, B. Nutrient Uptake in Mycorrhizal Symbiosis. Plant Soil 1994, 159, 89-102.

39. Jakobsen, I. Transport of Phosphorus and Carbon in VA Mycorrhizas. In Mycorrhiza; Varma, A., Hock, B., Eds.; Springer-Verlag: Berlin, 1995; 297-324. 
40. Koide, R.T. Tansley Review No. 29: Nutrient Supply, Nutrient Demand and Plant Response to Mycorrhizal Infection. New Phytol. 1991, 117, 365-386.

41. Smith, F.A.; Smith, S.E. Pathways, Mechanisms and Efficiency of Phosphate Transfer in Vesicular-arbuscular Mycorrhizal Roots. Acta Phytogeogr. Suec. 1996, 81, 119-125.

42. Jakobsen, I.; Abbott, L.K.; Robson, A.D. External Hyphae of VesicularArbuscular Mycorrhizal Fungi Associated with Trifolium subterraneum L. 2. Hyphal Transport of ${ }^{32}$ P Over Defined Distances. New Phytol. 1992, 120, 509-516.

43. Pearson, J.N.; Abbott, L.K.; Jasper, D.A. Phosphorus, Soluble Carbohydrates and the Competition Between Two Arbuscular Mycorrhizal Fungi Colonizing Subterranean Clover. New Phytol. 1994, 127, 101-106.

44. Joner, E.J.; Jakobsen, I. Contribution by Two Arbuscular Mycorrhizal Fungi to P Uptake by Cucumber (Cucumis sativus L.) from ${ }^{32} \mathrm{P}$-labelled Organic Matter During Mineralization in Soil. Plant Soil 1994, 163, 203-209.

45. Ahiabor, B.D.; Hirata, H. Characteristic Responses of Three Tropical Legumes to the Inoculation of Two Species of VAM Fungi in Andosol Soils with Different Fertilities. Mycorrhiza 1994, 5, 63-70.

46. Bürkert, B.; Robson, A. ${ }^{65} \mathrm{Zn}$ Uptake in Subterranean Clover (Trifolium subterraneum L.) by Three Vesicular-Arbuscular Mycorrhizal Fungi in a Root-free Sandy Soil. Soil Biol. Biochem. 1994, 26, 1117-1124.

47. Pearson, J.N.; Jakobsen, I. The Relative Contribution of Hyphae and Roots to Phosphorus Uptake by Arbuscular Mycorrhizal Plants, Measured by Dual Labelling with ${ }^{32} \mathrm{P}$ and ${ }^{33} \mathrm{P}$. New Phytol. 1993, 124, 489-494. 